\title{
The Construction of the Network Platform of Electronic Business English Teaching Based on Curriculum Theory
}

\author{
Lv Yixian, Yu Huijun \\ Jiangxi Teachers College, Yingtan, Jiangxi, 335000, China
}

Keywords: E-commerce English; network platform; curriculum theory; teaching course

\begin{abstract}
The information of vocational education requires the integration of information technology and higher vocational education. The construction of Web-based English teaching resources platform is the basis for the realization of this goal. The platform adopts Web application system based on B/S structure, using .NET framework technology and SQL Server database technology to establish a real-time, interactive and open electronic business English course design and teaching resources platform. To realize the sharing of teaching resources, promote the exchange and update of resources, as well as to improve the utilization of teaching resources and the ability of students' autonomous learning.
\end{abstract}

\section{Introduction}

With the continuous development of information technology and the popularity of the Internet, more and more individuals and businesses began to get involved in e-commerce sites. Individuals and enterprises to conduct business activities in the English Web site or the use of English web pages, strong English language skills are essential [1-3]. The outline of the national medium and long term educational reform and development plan points out that we should speed up the process of education information and strengthen the development and application of high quality educational resources. Strengthen the construction of network teaching resources database, develop the network learning course. Innovate the network teaching mode, strengthen the application of information technology, improve the level of application of information technology teachers, update teaching concepts, improve teaching methods and teaching effectiveness [4-5].

Students should be encouraged to use information technology to study independently and enhance their ability to analyze and solve problems by using information technology. The current national quality curriculum resources network has been built tens of thousands of door of vocational courses, but the search for "English" electronic commerce course, yet to meet the learning needs of students in higher vocational colleges, the construction of online English course of e-commerce teaching resources and network teaching platform has certain practical significance. The change of the curriculum goal is often dependent on the needs of the society, the school and the individual [6-8]. Meanwhile, the change of the curriculum goal will influence the society, the school and the individual. In this paper, under the guidance of curriculum objectives (syllabus or curriculum requirements), the paper discusses and studies the construction of the network platform of electronic business English teaching from the perspective of curriculum theory.

\section{The Construction of the Network Platform of E-commerce English Teaching}

\subsection{Implementation Technology of Network Teaching Resources Platform}

This platform uses the communication, performance, storage, application, database services, five types of network application module architecture, Web technology platform. Using the browser/server and .NET framework technology as well as SQL Server database technology, we designs and establishes a real-time, interactive teaching resources platform. The application of Silver light and AJAX technology is the two characteristics of this system. The framework design of network teaching resources platform is shown in Fig. 1. 


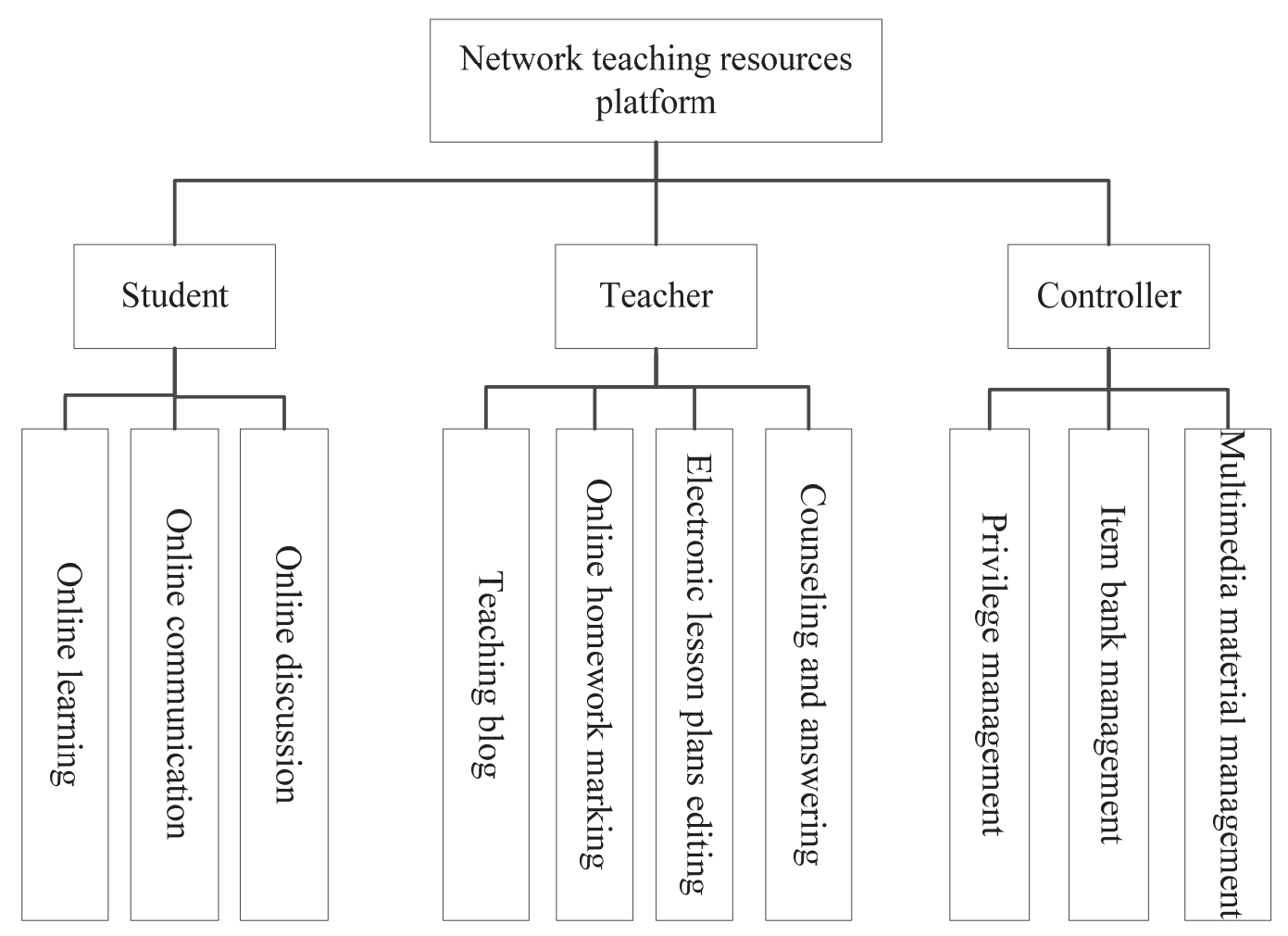

Fig1. System function flow chart

\subsection{The Development of Electronic Business English Teaching Resources}

E-commerce is a new business model based on the Internet, which is characterized by the commercial activities on the Internet in a digital way to complete, so the research of teaching resources construction around the content. After investigation, network information collection and visited the students understand in international and domestic e-commerce knowledge required ability and quality requirements and occupation skill, determine the location of electronic business English curriculum, English curriculum standards for the development of e-commerce. By learning this course, students can read about electronic business e-commerce transaction mode of e-commerce online payment security technology of e-commerce logistics management, e-commerce system implementation of network marketing English article. Able to master a variety of electronic commerce commonly used vocabulary and expression methods, and comprehensively improve students' ability to read and understand the electronic commerce English information, the use of the network to communicate in English and engage in e-commerce. To improve the students' business English writing ability, to master the operation principle of the method and steps of electronic commerce basic transaction type, which can build English network advertising, network marketing, network recruitment and job seekers network in English and understand foreign English shopping website and website in the sale of goods etc. In a word, the electronic commerce English teaching aims to cultivate three kinds of abilities: language ability, professional ability and general ability. Specifically, in the teaching of E-commerce English courses, students should have the basic ability of listening, speaking, reading and writing. In this process, review the basic knowledge and basic skills of electronic commerce, and through the flexible choice of teaching content and teaching strategies, some universal ability to strengthen students' communication skills, including cooperative ability, leadership innovation ability training.

\section{The Construction of Network Platform for Teaching Resources of E-commerce English Course}

In the course of teaching, teachers pay great attention to the cultivation of students' practical ability. The main jobs of college students majoring in business English for network trade and network customer service, so good communication ability is very important, teachers in the teaching process 
mainly improve students' English ability in business writing translation training [9]. For this reason, in the school, the teachers use multimedia language laboratory to pay attention to the classroom training, cultivate the students' communicative competence. Teachers design related training projects before class, such as telephone, product promotion, recruitment, company introduction, price negotiation simulation practice site business communication, role play and dialogue performance or business writing training.

The teacher in the multimedia language lab directly use the cyber source playing and teaching related video, audio, or directly on Taobao, Alibaba and other types of e-commerce sites, to give students demonstration of online shopping and online payment procedures [10-11]. After class, the students are asked to browse the website of Chinese and foreign enterprises or companies, which can carefully read the wording and layout of Chinese and foreign websites and compare with the English translation of foreign enterprise websites. In the school, expanding the practice base for students, internship and graduation practice platform. In addition, let the students experience the joy of online shopping, Taobao registered members of the online shopping experience, choose their favorite baby and to buy, DIY Taobao shop etc. After hard work, the network platform of the course was built. The framework of the network teaching platform of E-commerce English course is as follows, which is as shown in Fig. 2.

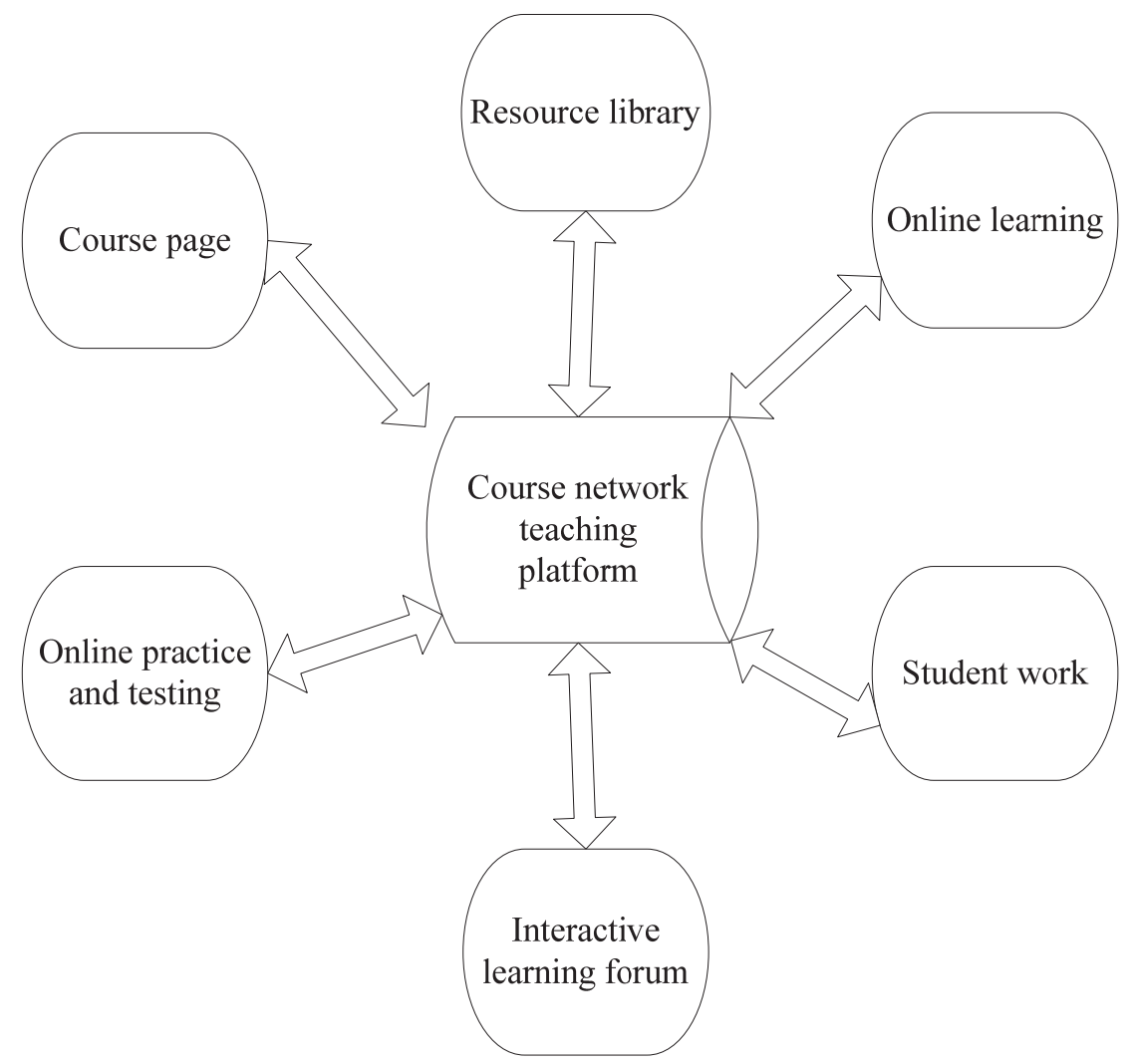

Fig. 2. Course network teaching platform

(1) Course page. Including curriculum, course introduction, curricula, teaching methods and teaching effect, curriculum standards, students through reading, it can understand the history of electronic business English courses, studying the curriculum objectives and requirements.

(2) Resource pool. A team of teachers curriculum teaching plans, teaching plans, reading data, video, Web links and other resources, students can play video, reading and extracurricular courses, learning English and e-commerce related knowledge through the network link. All teaching resources can be opened to students, students need to download the teacher's lectures and other teaching materials through the network to carry out independent learning.

(3) Online learning. Online learning to clear the specific requirements of each unit of the course requires students to provide teaching materials, exercises, simulation questions and other reference materials. So that students can review the contents of the class after class, and strengthen the classroom knowledge through practice. 
(4) Student works. The module is divided into two parts, one is the use of the network for students to communicate business correspondence, and the other is the student's project assignments, the main form is PPT. Students can submit their homework online, and teachers can communicate online, Q\&A, although teachers and students do not meet in the classroom, which can still keep in touch through the network to complete the teaching of the course.

(5) Online exercises and tests. Students through online practice test mastery, their knowledge gaps, consolidate and strengthen the curriculum content, expanding knowledge, improve the ability of autonomous learning.

(6) Interactive learning forum. Interactive learning forum can let students exchange learning, sharing the harvest, troubleshoot, show results, and which will study the problems encountered in the process displayed by the virtual community. Synchronous or asynchronous communication in the learning forum, to carry out discussions, sharing of learning outcomes, so that the study is not only the real classroom based, but also the guidance and help of invisible characters.

The problems and prospects for the construction of the network platform of e-commerce English teaching are as Table1.

Table 1. Examples of vocabulary unequal

\section{Existing problems \\ Lack of appropriate teaching materials}

Lack of teachers

Lack of training base

The use of the site is low
Construction outlook

Strengthening the construction of teaching materials

Strengthening the construction of teaching staff

Strengthen the training base construction

Updating network teaching resources

\section{Summary}

Through the teaching practice, the college English teaching of electronic commerce in the teaching methods and means, the construction of teaching staff and other aspects have made some practical results, the network teaching resources in the course is also initially completed. However, the hardware and software environment of electronic business English teaching needs to be further improved. In the future, it is necessary to update the teaching content according to the requirements of the continuous development of e-commerce, and constantly supplement the teaching resources. Make full use of the existing teaching resources, to build a dynamic update to enhance the interaction between teachers and students in the course of learning outside the classroom, more conducive to students in the practice of independent learning network platform.

\section{References}

[1] Zhang X P, Wu D H. Construction and Practice of P.E. Network Course Based on Module Theory in University[J]. Lecture Notes in Electrical Engineering, 2014, 269:3103-3110.

[2] Li G. Curriculum construction of analog electronic technology based on BB teaching platform[J]. Electronic Test, 2013.

[3] Chu C. Construction of a teaching simulation platform based on university English curriculum system[C]// IEEE Workshop on Electronics, Computer and Applications. IEEE, 2014:726-728.

[4] Zhang J. On the Construction of Resource-Library-Based Network Teaching Platform of English Extensive Reading[M]. IEEE Computer Society, 2009.

[5] En L U, Chen G, Humanities D O. Construction of Network Platform for E-commerce English Curriculum Teaching and Learning Resources in Higher Vocational Colleges[J]. Journal of Beijing Polytechnic College, 2015.

[6] Wei X. A Study on the Constructing of Practical Curriculum Platform of English Majors' Comprehensive Ability - from the Perspective of the Curriculum Theory[J]. Overseas English, 
2014.

[7] Zhu W, Cheng Z. An Empirical Study on the Curriculum Construction of Business English for International Trade Based on the Case of GDUFS[J]. English Language Teaching, 2013, 6(4).

[8] Liu Y. Construction of Flipped Classroom Teaching Mode for College English Based on Network Teaching Platform[C]// International Conference on Social Science, Education and Humanities Research. 2016.

[9] Huang C F. The Curriculum Construction Ideas of Extensive English Reading for Tourism Based on the Guide of Project Teaching[J]. Journal of Hunan University of Arts \& Science, 2008.

[10] Meng F M. Construction of Multimedia Network English Teaching System Based on Ubiquitous Learning Theory[J]. Modern Educational Technology, 2010.

[11] Luo C C, Institute G T. Practice Teaching Mechanism Construction of "Dual-task an Dual-tutor” Based on Curriculum Theory[J]. Journal of Tangshan Vocational \& Technical College, 2014. 